
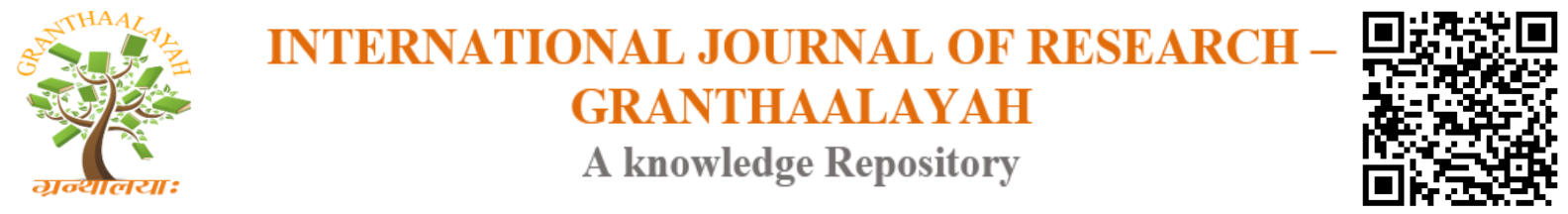

Management

\title{
A STUDY ON GOLD AS A SAFER INVESTMENT ALTERNATIVE AMONG SMALL AND MEDIUM INVESTORS WITH SPECIAL REFERENCE TO KOZHIKODE DISTRICT
}

\author{
Shobha C. V. *1 \\ ${ }^{* 1}$ Assistant Professor, Department of Commerce, St. Joseph College (Autonomous) Devagiri, \\ Kozhikode Kerala, India
}

\begin{abstract}
Among the various precious metals "Gold" is the most popular as an investment. Why it is so? The answer is it is a mainstream asset as it is not only an effective diversifier but also gives a competitive return when compared to major financial assets. The present study analyses 'Gold as a safer investment alternative' by examining its risk and return in terms of other investment alternatives like stock and bond. The risk and return analysis of an asset class is better studied with its volatility measurement. The present study uses daily prices of gold, stock Nifty 5o, and India Government Bond. To measure the volatility of time series, Generalized autoregressive Conditional Heteroskedasticity $\operatorname{GARCH}(1,1)$ process is used the results shows that risk in terms of volatility of gold prices is $0.970124(<1)$ which showed less when compared to stock(is $0.956541(<1)$ and bond $(1.003183(>1)$ risk. This study also analyses various demographical factors that influence on the decision to invest in gold and as well as in selecting a particular kind of gold investment. The chi-square test was applied and the results showed that all the variables under study except education qualification (' $p$ ' value 0.8308 ) dictated investors decision in selecting gold as an investment opportunity.
\end{abstract}

Keywords: Volatility; Generalized Autoregressive Conditional Heteroskedasticity; Arch effect.

Cite This Article: Shobha C. V.. (2017). "A STUDY ON GOLD AS A SAFER INVESTMENT ALTERNATIVE AMONG SMALL AND MEDIUM INVESTORS WITH SPECIAL REFERENCE TO KOZHIKODE DISTRICT." International Journal of Research - Granthaalayah, 5(11), 27-45. https://doi.org/10.29121/granthaalayah.v5.i11.2017.2324.

\section{Introduction}

Personal savings has an important role to play in the economy of any country. Savings and Investment is considered as a powerful tool in eradicating poverty. To invest means to allocate money or other resources with the hope to get a benefit in the future. This benefit we call 'Return'. Investors generally expect higher return from their investment. There are numerous asset classes or investment avenues for an investor in this globalised economy. These avenues can be broadly classified as Financial Investment and Real Investment. In the present economic 
scenario we prefer the kind of investment that protect our wealth rather than create our wealth. Gold is such a 'Real Asset', that still continues to be preferred as safe-haven asset for investors globally. Investors generally buy gold as a way of diversifying risk especially in capital market through the use of futures contracts and derivatives. The gold market is subject to speculation and volatility as are other markets. The modern gold market is a picture of diversity and growth. Since the early 1970s, the volume of gold produced each year has tripled, the amount of gold bought annually has quadrupled and gold markets have flourished across the globe. Gold is now bought by a far more diverse set of consumers and investors than at any previous time in history. Based on a ten year average demand estimate ending 2016, (WGC) average annual demand is 4100 tonnes (approx. US \$166bn).Among this about 54\% demand goes for jewellery, 30\% for investment (gold bars, gold coin, gold ETF), 10\% for technology, 6\% in central banks. According to world Gold council, a single mobile device contain up to 50 milligram of gold, which is a tiny amount but nearly 1 billion cell phones are produced every year with a gold value of about 50 cents in each phone, which add up to $\$ 500$ million in gold each year. Why invest in gold? The answer is gold is a unique asset, highly liquid, yet scares. It acts a diversifier, a vehicle to mitigate losses in times of market stress and a competitive asset which serves as a hedge against inflation and currency risk. Gold is seen as a valuable commodity with an intrinsic value. Unlike other commodity the value of gold is less affected by consumption but largely by the state of the economy. Following the global financial crises, there was a continued growth in consumer gold demand across globe and the strength of Asian gold demand literally reinforced the global gold market. According to WGC latest gold demand trends reports. Global demand for Gold in the second quarter was 953 tonnes, a fall of $10 \%$ compared with the same period of 2016. The comparison suffers due to the record inflow of ETF in 2016. Bar and coin investment constrastically showed a positive market, as was with the jewellery demand also, technology demand also made a modest gain.

In India, Gold is believed by the expert and layman equally to be the most robust mode of investment. Undoubtedly, it is the most favorite investment avenue in the India. And for the right reason the performance of gold has far surpassed the equity market and the real estate as seen for the last 10 years. Though in the early phase of 2017 the market witnessed a fall in the prices of gold, experts still believe this phase is only transitory and will pass soon. "Gold is considered to be a symbol of prosperity, good fortunes and has an inherent value in terms of purity and wealth. Indians hold more gold than any other population. The hunger for gold has resulted in India's import for gold constituting a massive $12.50 \%$ of its total imports in 2012-13. In 2012, the total gold production in the world stood at 4,130 tones and India imported $26.12 \%$ of that which is $1 / 4$ the of the world's total gold production. India's gold imports could hit 450 tones in the first half of the current year (2017), which is more than the double from the same period in 2016. According to the industry sources gold demand in the coming months will continue to remain good even after the 3\% GST. India's gold demand in Q2 2017 was a robust quarter as seasonal demand and positive sentiments returned with remonetization and expectation of a good monsoon contributed a year-on-year increase with a healthy rise of gold demand despite a low base of Q2, 2016. 


\section{Statement of the Problem}

If there was ever an indicator of wealth and prosperity it is 'GOLD'. Gold is viewed globally by investors as an 'Asset' to hold during periods of market fluctuations and to sell when the economy is flourishing. But on the contrary; economic growth has always influenced the gold demand positively. Studies shows that investors prefer gold during periods of market uncertainty; pushing the demand up during inflation or when the stock market tumbles. This generally influences gold prices in the short-run. However, a positive income growth will invariably influence the consumer demand for gold even in the long run. Moreover, an ever expanding global middle class has also created a source of positive momentum for 'Gold'. The bigger question is "Is Gold a safe investment avenue"? The answer is gold is a unique asset, highly liquid, yet scares. It acts a diversifier, a vehicle to mitigate losses in times of market stress and a competitive asset which serves as a hedge against inflation and currency risk. How do we say an investment is safe? Safety of an investment is measured in terms of its 'Risk'. In this context, this research study focuses on "why investment in Gold is still considered a step ahead other alternative investments among small and medium investors?

\section{Objective of the Study}

1) To find whether Gold investment is safer than other alternative investments like stock and government bond in the present economic situation.

2) To find the factors influencing the small and medium investors on the decision to invest in gold or not.

3) To find out factors influencing the decision on the kind of gold investment they make.

\section{Research Methodology}

\subsection{Research Design}

A research is purely and simply the framework and plan for the study that guides the collection and analysis of data. 'Analytical research' technique was adopted in the project. Analytical research is designed to analyze the facts/information available to make a critical evaluation. 3

\subsection{Source of Data}

Both Primary and secondary data is used for doing this project. Primary data was collected through a structured questionnaire from a sample of 100 in Kozhikode district. Secondary data related to Gold daily prices $1^{\text {st }}$ quarter of (2012-2017) was collected from www.keralagold.com. Data related to stock index Nifty $501^{\text {st }}$ quarter of (2012-2017) was collected from www.nseindia.com. Data related to India Government bond yield $1^{\text {st }}$ quarter of (2012-2017) was collected from http://in.investing.com. Apart from that various journals, other websites were also used for secondary data. 


\subsection{Sampling Method}

Number of samples selected is 100. Simple random sampling is the sampling technique adopted to select samples for this study.

\section{Tools of Statistical Analysis}

\subsection{Garch $(1,1)$}

There are various measures of volatility. Modeling and forecasting volatility is perhaps the most important area of research in the whole of finance in the last two decades. Volatility as measured by the standard deviation or variance of returns is often used as crude measure of the total risk of financial asset. It involves calculating the variance or standard deviation of returns in the usual way over some historical period and this then becomes the volatility in asset returns. Thus we want a measure of volatility that changes over time. Such a measure of time varying volatility is known as Autoregressive Conditional Heteroskedasticity $(\mathrm{ARCH})$ was first suggested by Engle (1982). The original model was later extended in many directions one of this was GARCH

\subsection{Garch Model}

One of the drawbacks of ARCH specification, according to Engle (1995), was that it looked more like a moving average specification than an auto regression. From this, a new idea was born which was to include the lagged conditional variance terms as autoregressive terms. This idea was worked out by Tim Bollerslev, who in 1986 published a paper entitled 'Generalised Autoregressive Conditional Heteroskedasticity' in journal of Econometrics, starting new family of GARCH model.

The GARCH $(\mathrm{p}, \mathrm{q})$ model

The general GARCH (p, q) model has following form:

$Y t=a+\beta^{\prime} X t+u t$

$u t \mid \Omega t \sim \operatorname{iidN}(0, h t)$

$h t=\gamma 0+\sum_{i=1}^{p} \delta i h t-i+\sum_{j=1}^{q} \gamma j u^{2} t-5$

Which says that the value of the variance scaling parameter ht now depends both on past values of shocks which are captured by the lagged squared residual terms, and on the past values of itself, which are captured by lagged ht terms

It should be clear to reader by now that for $\mathrm{p}=0$ the model reduces to $\mathrm{ARCH}(\mathrm{q})$.

The simplest form of the GARCH (p, q) model is $\operatorname{GARCH}(1,1)$ model for which the variance equation has the form:

$h t=\gamma 0+\delta 1 h t-1+\gamma 1 u^{2} t-1$ 
This model specification usually performs very well and is easy to estimate because it has only three unknown parameters $\gamma_{0}, \gamma_{1}$ and $\delta_{1}$.

The GARCH $(1,1)$ Model

To show that the GARCH $(1,1)$ is a parsimonious alternative to an infinite $\operatorname{ARCH}(q)$ process consider equation

$h t=\gamma 0+\delta h t-1+\gamma 1 u^{2} t-1$

$=\gamma 0+\delta\left(\gamma 0+\delta h t-2+\gamma 1 u^{2} t-2\right)+\gamma 1 u^{2} t-1$

$=\gamma 0+\gamma 1 u^{2} t-1+\delta \gamma 0+\delta^{2} h t-2+\delta \gamma 1 u^{2} t-2$

$=\gamma 0+\gamma 1 u^{2} t-1+\delta \gamma 0+\delta^{2}\left(\gamma 0+\delta h t-3+\gamma 1 u^{2} t-3\right)+\delta \gamma 1 u^{2} t-2$

$=\frac{\gamma 0}{1-\delta}+\gamma 1\left(u^{2} t-1+\delta u^{2} t-2+\delta^{2} \gamma 1 u^{2} t-3+\cdots\right)$

$=\frac{\gamma 0}{1-\delta}+\gamma 1 \sum_{j=1}^{\infty} \delta j-1 u^{2} t-j$

Which shows that the GARCH $(1,1)$ specification is equivalent to an order ARCH model with coefficients that decline geometrically. For this reason it is essential to estimate GARCH $(1,1)$ models as alternative to high - order ARCH model because with the GARCH $(1,1)$ we have less parameter to estimate and therefore lose fewer degrees of freedom.

\subsection{Chi-Square}

To assess the association between demographical factors while making investment in gold, we use the Chi-square test for independence the hypothesis test for independence is:

Ho: The two classification variables are independent of each other.

H1: The two classification variables are not independent.

The Chi-square test statistic for independence

$x^{2}=\sum^{r} \sum^{c} \frac{\left(O_{i j}-E_{i j}\right)^{2}}{E_{i j}}$

$\mathrm{i}=1, \mathrm{j}=1$

With degree of freedom as (r-1)(c-1).The null hypothesis is rejected if sample $\chi^{2}$ at chosen level of significance.

\section{Review of Literature}

Fu-lai lin, Sheng-Yung Yang, Terry Marsh, Yu-Fen Chen (2017) international Review of Economics and finance "Stock and bond return relations and stock market uncertainties evidence from Wavelet analysis" investigates the time variation features of stock-bond return relation across different frequencies from 1988 to 2014. They also tried to examine whether time variation features of stock-bond return relation can be linked to two dimension; fundamental economic factor and stock market uncertainty. The empirical results show that the short-term and long-term dependencies between stocks and bonds did vary over time. In addition, the relations between stock and bond returns have positive sign sensitivity to the short rate and the slope of term structure, while their sensitivity to stock market volatility is negative. Moreover, the impact 
of crises on the long-term stock-bond relation is significantly negative and the impact on shortterm relation is significantly positive. Hence, the fundamental economic factors which drive the stock-bond relations do not vary across time frequencies; however, the impacts of crises do vary across the time frequencies.

Cuong Nguyen, M Ishag Bhatti, Magde Komornikova, Jozef Komornikova; Economic Modelling vol. 58, Nov. 2016. This paper investigates the role of gold as a safe haven in international stock markets using various copula techniques to capture complex dependencies between stock markets and gold prices The paper employs parametric and nonparametric copulas to over 11 years of daily data (1999-2010) from seven countries' to understand the nexus between international stock markets and gold prices. The results show that gold may be a safe haven asset during market crash for the case of Malaysia, Singapore, Thailand, the UK and the US markets but not for the Indonesian, Japanese and the Philippines markets.

Dirk G Thomas, Thomas K. McDermott (2009) Journal of Banking and Finance, volume 34 issue 8 august 2010, "Is gold a safe haven against stock market", examines the role of gold in the global financial system. A descriptive and econometric analysis for a sample spanning a 30 years period from 1979 to 2009 shares that gold both a hedge and a safe haven for major European stock markets and US and not for emerging market like BRIC countries. The study found that gold was a strong safe haven for most developed markets during the peak of that recent financial crisis.

Dr. Sindhu, (2013) - "A study on impact of selected factors on the price of gold" - The objective of the study was to analyze the different factors which affect the price of gold. In this study they analyzed the impact of exchange rate of USD with INR, prices of crude oil, repo rate and inflation on gold prices, separately. They mainly used multiple regression models to study the impact of these factors on gold prices. They found that gold price and dollar value share an inverse relationship; gold prices and crude oil prices share a positive correlation: gold price and repo rate are negatively correlated. And gold prices and inflation rates are positively correlated. Prerna Baber, Ruturaj Baber and Dr. George Thomas, (2013) - "Factors affecting gold prices: A case study of India" - This study examines the various factors contributing towards continuously escalating prices of gold in India and how factors like international business environment, political environment, market conditions, its induction in commodity markets, buying behavior of consumers and inflation have affected prices of gold during last decade. The study made use of trend analysis. The test result reveals that there are positive correlations between gold prices and with all other major factors.

Devdutt Pattanaik (2013) -“Sacred Gold"- This research work was published by World Gold Council mainly focuses on the mythological and cultural significance of gold in India. According to him Indians love gold and this has been explained logically and culturally. Logically, gold is a tangible investment, unlike shares and bonds; a portable investment, unlike property and a beautiful ornament, one that can be worn daily on the body as jewellery.

P. K. Mishra, J. R Das, S. K. Mishra (2010) American Journal of scientific Research -“Gold price volatility and stock market returns in India" attempts to analyze the casusality relation that may run between domestic gold prices and stock market return in india. The study takes into 
consideration the domestic gold prices and stock market returns based on BSE 100 index, investigates the Granger causality in the vector error correction Model for the period January 1991 to December 2009 and finds that the gold prices Granger-causes stock market returns and stock market returns also Granger-causes the gold prices in india during the sample period.

Rakesh kumar Sharma (2016) Journal of International Economics, Volume 7, issue 1, Forecasting gold prices with Box Jenkins Autoregressive integrated moving average method". This paper attempts to develop a forecasting model for gold prices in india. The monthly sample data of gold prices were taken from $1^{\text {st }}$ January 1995 to $1^{\text {st }}$ june 2014 have used to build the model. The Unit root test of Augmented Dickey Fuller II and Philip person have been used to test the gold price series as stationary or non-stationary. It is observed that series were stationary at first difference. Box Jenkins methodology has been used for developing a forecasting model of gold price in India. ARIMA (3, 1, and 3) is best suitable to predict the gold price in India

\section{Data Analysis and Interpretation}

\subsection{Gold is a Safer Investment Alternative When Compared to other Investments- An Empirical Analysis}

The present study is based on the daily prices of Gold, stock (Nifty 50), and Bond for a period from 2012-2017. Since the study aims to measure the volatility of gold prices, stock index and bond yield, all these are used in terms of log difference to form a model of mean equation and variance equation. There are various measures of volatility. To measure the volatility of time series, generalized autoregressive conditional heteroskedasticity $(\mathrm{GARCH})$ process is used. It is an econometric term developed in 1982 by Robert F.Engle, to describe an approach to estimate volatility in financial markets.

\subsubsection{Gold}
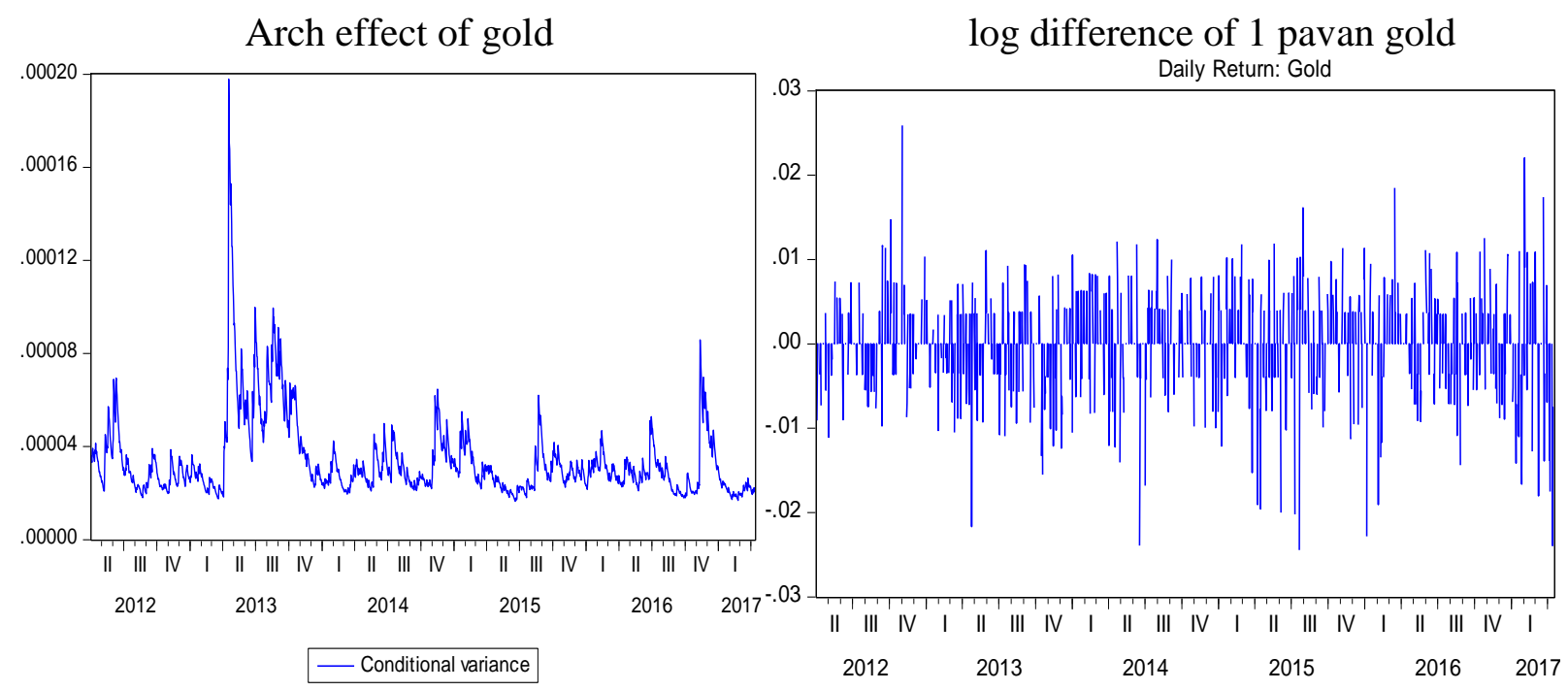

(Source: Secondary data) 


\section{Risk and Return Analysis of Gold}

Dependent Variable: DLOG(PRICE_OF_1_PAVAN_GOLD_R)

Method: ML - ARCH (Marquardt) - Normal distribution

Date: $05 / 15 / 17$ Time: $14: 57$

Sample (adjusted): 4/02/2012 4/12/2017

Included observations: 1837 after adjustments

Convergence achieved after 16 iterations

Presample variance: backcast (parameter $=0.7$ )

$\mathrm{GARCH}=\mathrm{C}(2)+\mathrm{C}(3) * \operatorname{RESID}(-1)^{\wedge} 2+\mathrm{C}(4) * \mathrm{GARCH}(-1)$

\begin{tabular}{lllll}
\hline \hline Variable & Coefficient & Std. Error & z-Statistic & Prob. \\
\hline \hline $\mathrm{C}$ & $4.73 \mathrm{E}-05$ & 0.000124 & 0.380026 & 0.7039 \\
\hline \hline \multicolumn{4}{l}{ Variance Equation } & \\
\hline \hline $\mathrm{C}$ & $1.01 \mathrm{E}-06$ & $1.72 \mathrm{E}-07$ & 5.860286 & 0.0000 \\
$\mathrm{RESID}(-1)^{\wedge} 2$ & 0.049751 & 0.004318 & 11.52302 & 0.0000 \\
GARCH(-1) & 0.920373 & 0.007992 & 115.1615 & 0.0000 \\
\hline \hline R-squared & -0.000006 & Mean dependent var & $3.24 \mathrm{E}-05$ \\
Adjusted R-squared & -0.000006 & S.D. dependent var & 0.005844 \\
S.E. of regression & 0.005844 & Akaike info criterion & -7.530559 \\
Sum squared resid & 0.062694 & Schwarz criterion & -7.518548 \\
Log likelihood & 6920.818 & Hannan-Quinn criter. & -7.526130 \\
Durbin-Watson stat & 1.824193 & & \\
\hline \hline \hline
\end{tabular}

\section{Interpretation}

The above mentioned is the result of risk and return analysis generated using E-views software gold price, the mean equation and variance equation generated by the software is used to calculate the risk and return of the stock, mean equation represent daily return from gold. To obtain the annual return we have to multiply with 250 (250 observation exist in single year). Variance equation is used to calculate risk, variance equation consist of two coefficients ARCH $(\beta) /\left(\operatorname{RESID}(-1)^{\wedge} 2\right)$ and $\operatorname{GARCH}(\alpha)$. $\mathrm{ARCH}(\beta)$ represents the impact of previous day volatility on today volatility; on the other hand GARCH $(\alpha)$ is used to measure the persistence of volatility. In the case of Gold Prices both are significant i.e. $(\mathrm{p}<.05)$. Thus Risk is the sum of ARCH $(\beta)$ and GARCH $(\alpha)$. If sum obtained is closer to 1 then the investment is considered as risky other ways it is considered as less risky

\begin{tabular}{|l|l|l|}
\multicolumn{3}{c}{ Risk $=\mathrm{ARCH}(\beta)+\mathrm{GARCH}(\alpha)$} \\
\hline gold & Amount & Amount \\
\hline Risk & $0.049751+0.920373$ & 0.970124 \\
\hline Return & $.0000473 * 250 * 100$ & $1.1825 \%$ \\
\hline
\end{tabular}

Since the value of risk is closer to $\mathbf{1}$ investment in gold is considered as high risky and it provides a return of $1.1825 \%$ 


\subsubsection{Stock}

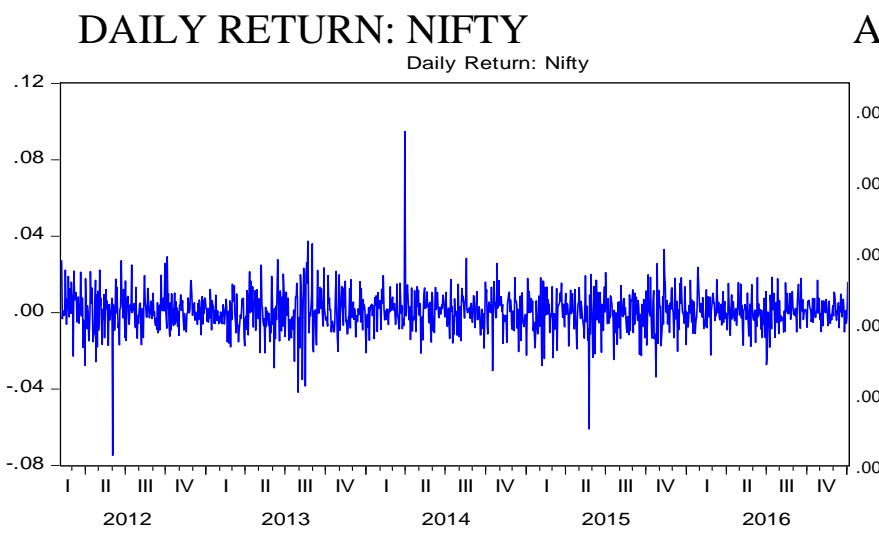

ARCH EFFECT: NIFTY RETURN

(Source: Secondary Data)

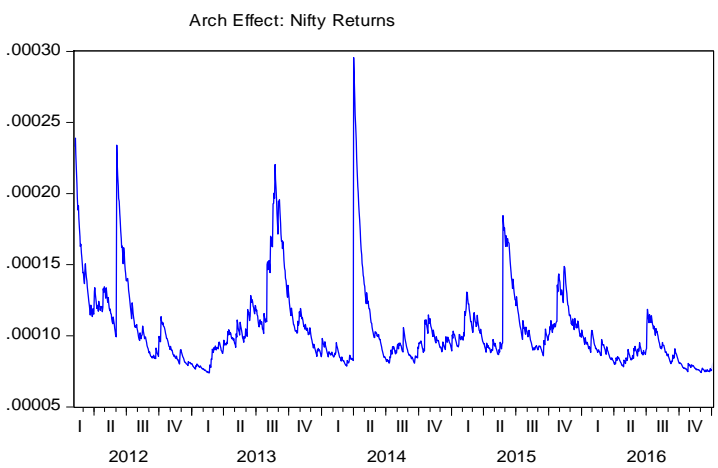

\section{Risk and Return Analysis of Stock}

Dependent Variable: LOGCLOSE

Method: ML - ARCH (Marquardt) - Normal distribution

Date: 08/19/17 Time: 20:13

Sample (adjusted): 2/07/2012 1/05/2017

Included observations: 1283 after adjustments

Convergence achieved after 34 iterations

Presample variance: backcast (parameter $=0.7$ )

$\mathrm{GARCH}=\mathrm{C}(2)+\mathrm{C}(3) * \mathrm{RESID}(-1)^{\wedge} 2+\mathrm{C}(4) * \mathrm{GARCH}(-1)$

\begin{tabular}{lllll}
\hline \hline Variable & Coefficient & Std. Error & Z-Statistic & Prob. \\
\hline \hline C & 0.000627 & 0.000301 & 2.080021 & 0.0375 \\
\hline \hline & \multicolumn{2}{l}{ Variance Equation } & & \\
\hline \hline C & $4.47 E-06$ & $9.38 E-07$ & 4.764752 & 0.0000 \\
RESID(-1)^2 & 0.024137 & 0.006444 & 3.745387 & 0.0002 \\
GARCH(-1) & 0.932404 & 0.013589 & 68.61294 & 0.0000 \\
\hline \hline R-squared & -0.000034 & Mean dependent var & 0.000568 \\
Adjusted R-squared & -0.000034 & S.D. dependent var & 0.010189 \\
S.E. of regression & 0.010189 & Akaike info criterion & -6.350136 \\
Sum squared resid & 0.133091 & Schwarz criterion & -6.334058 \\
Log likelihood & 4077.612 & Hannan-Quinn criter. & -6.344100 \\
Durbin-Watson stat & 1.899948 & & \\
\hline \hline
\end{tabular}

(Source: Secondary Data) 


\section{Interpretation}

The above mentioned data is the result of the risk and return analysis generated using E-views software regarding NSE S\&P nifty 50 prices of $1^{\text {st }}$ quarter of $2012-1^{\text {st }}$ quarter of 2017 . The mean equation and the variance equation generated by the software are used to calculate the risk and return analysis of the stock. To obtain the annual return we multiplied with 250 (250 observation exist in single year). Variance equation is used to calculate risk. Variance equation consist of two coefficients $\operatorname{ARCH}(\beta) /\left(\operatorname{RESID}(-1)^{\wedge} 2\right)$ and $\mathrm{GARCH}(\alpha)$. ARCH $(\beta)$ represents the impact of previous day volatility on today volatility; on the other hand GARCH $(\alpha)$ is used to measure the persistence of volatility. In this case of stock index (Nifty 50 ) both ' $\beta$ ' and ' $\alpha$ ' are significant i.e. $(p<.05)$. Risk is the sum of ARCH $(\beta)$ and GARCH $(\alpha)$. If the sum obtained is closer to 1 then the investment is considered as risky other ways it is considered as less risky

(Risk = ARCH $(\beta)+$ GARCH $(\alpha))$
\begin{tabular}{|l|l|l|}
\hline Stock (nifty50) & Amount & Amount \\
\hline Risk & $0.024137+0.932404$ & 0.956541 \\
\hline Return & $.0000447 * 250 * 100$ & $1.1175 \%$ \\
\hline
\end{tabular}

Since the value of risk is closer to 1 investment in stock is considered a risky. When compared to gold return volatility it is less.

\subsubsection{Bond}

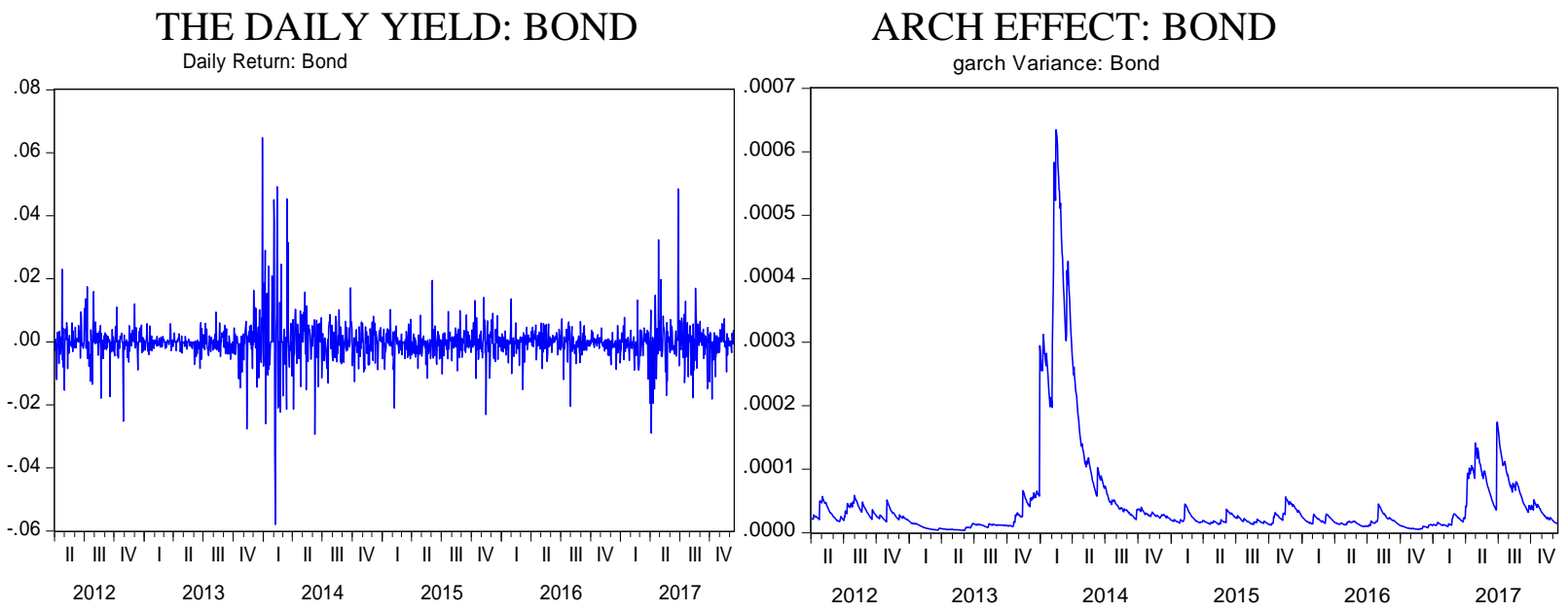

Dependent Variable: LOGPRICE

Method: ML - ARCH (Marquardt) - Normal distribution

Date: 08/19/17 Time: $21: 14$

Sample (adjusted): 4/03/2012 12/14/2017

Included observations: 1488 after adjustments

Convergence achieved after 17 iterations

Presample variance: backcast (parameter $=0.7$ )

$\mathrm{GARCH}=\mathrm{C}(2)+\mathrm{C}(3) * \mathrm{RESID}(-1)^{\wedge} 2+\mathrm{C}(4) * \mathrm{GARCH}(-1)$ 


\begin{tabular}{lllll} 
Variable & Coefficient & Std. Error & Z-Statistic & Prob. \\
\hline \hline $\mathrm{C}$ & -0.000277 & $9.90 \mathrm{E}-05$ & -2.800193 & 0.0051 \\
\hline \hline \multicolumn{4}{l}{ Variance Equation } & \\
\hline \hline $\mathrm{C}$ & $1.09 \mathrm{E}-07$ & $2.12 \mathrm{E}-08$ & 5.159356 & 0.0000 \\
$\mathrm{RESID}(-1)^{\wedge} 2$ & 0.056672 & 0.002558 & 22.15247 & 0.0000 \\
GARCH(-1) & 0.946511 & 0.001773 & 533.7869 & 0.0000 \\
\hline \hline R-squared & -0.000244 & Mean dependent var & -0.000175 \\
Adjusted R-squared & -0.000244 & S.D. dependent var & 0.006552 \\
S.E. of regression & 0.006553 & Akaike info criterion & -7.688812 \\
Sum squared resid & 0.063853 & Schwarz criterion & -7.674551 \\
Log likelihood & 5724.476 & Hannan-Quinn criter. & -7.683497 \\
Durbin-Watson stat & 1.843443 & \multicolumn{2}{l}{}
\end{tabular}

(Source: Secondary Data)

The above mentioned data is the result of the risk and return analysis generated using E-views software regarding prices of $1^{\text {st }}$ quarter of 2012- $1^{\text {st }}$ quarter of 2017 . The mean equation and the variance equation generated by the software is used to calculate the risk and return analysis of the stock. The mean equation represents daily return from nifty 50 . To obtain the annual return we multiplied with 250 (250 observation exist in single year). Variance equation is used to calculate risk. Variance equation consist of two coefficients ARCH $(\beta) /\left(\operatorname{RESID}(-1)^{\wedge} 2\right)$ and GARCH $(\alpha)$. ARCH $(\beta)$ represents the impact of previous day volatility on today volatility; on the other hand GARCH $(\alpha)$ is used to measure the persistence of volatility. In this case of GOI 10-YEAR Bond both ' $\beta$ ' and ' $\alpha$ ' are significant i.e. $(\mathrm{p}<.05)$. Risk is the sum of ARCH $(\beta)$ and GARCH $(\alpha)$. If the sum obtained is closer to 1 then the investment is considered as risky other ways it is considered as less risky

\begin{tabular}{|l|l|l|}
\multicolumn{3}{|c}{ Risk $=\mathrm{ARCH}(\beta)+\mathrm{GARCH}(\alpha))$} \\
\hline GOI 10 -year bond yield & Amount & Amount \\
\hline Risk & $0.056672+0.946511$ & 1.003183 \\
\hline Return & $.0000109 * 250 * 100$ & $0.2725 \%$ \\
\hline
\end{tabular}

As the risk is 1.003183 which is comparatively less than gold return and stock return, the return is comparatively low.

\subsection{Factors Influencing Investors Decision to Invest in Gold or Not-- An Analysis}

Behavioural biases have always found to affect investors differently based on their demographical characteristics. The analysis focuses on the factors and related variables influencing the decision to invest in Gold or not. This analysis is based on the primary data collected through a structured questionnaire distributed to the selected samples. Statistical tool 
Chi-Square is used to find how independent are the variables in deciding whether to invest in gold or not.

\subsubsection{Age}

Our ability to make sound financial decision depends largely on age. Hence to test whether age has influenced the investment decision, the related data was analysed.

Table 2: Age and Investment

\begin{tabular}{|l|l|l|l|}
\hline AGE & $>\mathbf{1 0} \%$ & $<\mathbf{1 0} \%$ & \multirow{2}{*}{$\chi^{2}=8.79$} \\
\cline { 1 - 3 }-35 & 34 & 19 & $\mathrm{P}=0.0124 * *$ \\
\hline $35-45$ & 26 & 7 & \\
\hline $45-55$ & 16 & 0 & \\
\hline
\end{tabular}

Source: Primary Data, $* *$ shows significance at $5 \%$

\section{Interpretation}

The above Table no. 3.2.1 shows the number of respondents who invest $>10 \%$ and $<10 \%$ of their savings in gold. Here investment of at least $10 \%$ in gold is taken as a measure for comparability. To find the association between age and the decision to invest in gold or not, a chi-square test has been used. Chi-square value obtained is 8.79 with 2 degree of freedom and the 'p' value is .0124 . ' $p$ ' value is the probability that a chi-square statistic having 2 degree of freedom is more extreme than 19.58 ie., $\mathrm{p}\left(\chi^{2}>19.58\right)=0.0124$. Here, the ' $\mathrm{p}$ ' value is less than the significance level (0.05), and the null hypothesis is rejected. Therefore, the study claims that 'Age' may dictate investor's in deciding their portfolio.

\subsubsection{Gender}

Gender differences are an important demographical variable while making investments. Studies have shown that while men prefer to invest in real estate, stocks women are more risk averse and is seen to invest more in gold especially jewellery and fixed income schemes. To test whether gender differences are there in investing in gold, a chi-square analysis is undertaken.

Table No.2 Gender and Investment

Source: Primary Data, $* *$ shows significance at $5 \%$

\begin{tabular}{|l|l|l|l|}
\hline INVEST & MALE & FEMALE & \multirow{2}{*}{$\chi^{2}=6.83$} \\
\cline { 1 - 3 } YES & 48 & 44 & $\mathrm{P}=0.0090 * *$ \\
\hline NO & 8 & 0 & $\mathrm{P}$ \\
\hline
\end{tabular}

\section{Interpretation}

The above Table No. 3.2.2 and the chart shows that almost all the female respondents invest in gold and a certain percentage of male respondents don't invest in gold. The chi-square test is used to find the association between gender and investment in gold. The chi-square value is 6.83 and the 'p' value is 0.0090 . ' $\mathrm{p}$ ' value is the probability that a chi-square statistic having 2 degree of freedom is more extreme than 19.58 ie., $\mathrm{p}\left(\chi^{2}>19.58\right)$ The results shows that the $\mathrm{p}$-value is 
significant with 0.0090 (less than $.05 \%$ ) with a degree of freedom of 1 . This analysis therefore finds that when gender is concerned, female investors are more attracted towards Gold investments.

\subsubsection{Educational Qualification}

In order to assess the impact of education on the decision making in their personal finance, the total respondents were classified as Post graduate, Graduated, and sslc/plus-two. The number of samples who responded yes and no according this variable are presented in the following table.

Table 3: Educational Qualification and Investment

\begin{tabular}{|l|l|l|l|l|l|}
\hline INVEST & PG & GRADUATE & SSLC/+2 & \% in Total & \multirow{2}{*}{${ }^{2}=0.43$} \\
YES & 40 & 48 & 4 & 92 & $\chi^{2}$ \\
\cline { 1 - 4 } NO & 4 & 4 & 0 & 8 & $\mathrm{P}=0.8308 * *$ \\
\hline
\end{tabular}

Source: Secondary Data, ${ }^{* *}$ Shows significance at $5 \%$

\section{Interpretation}

The above Table No. 3.2.3. Shows that about $88 \%$ of respondents with higher qualification have said that they invest in gold. Whereas $4 \%$ of respondents with higher educational qualification do not invest in gold. The chi-square test value obtained is 0.43 with degree of freedom 2 , the ' $p$ ' value obtained is 0.8308 ( $\mathrm{p}$ value is the probability that a chi-square value is more extreme than 19.58 i.e., ( $p>19.58$ ) which is more than $0.5 \%$ level of significance. Therefore educational qualification as a variable is not significant to investors while taking decision for investing in gold.

\subsubsection{Marital Status}

Among the various demographical variables affecting investment, marital status is one of the deciding factors. This is because, people after marriage make saving for their future living. The Table below shows the differences among the married respondents and the single investors while making investment in gold

Table 4: Marital Status and Investment

\begin{tabular}{|l|l|l|l|}
\hline INVEST & MARRIED & SINGLE & \multirow{2}{*}{$\chi^{2}=2.17$} \\
\cline { 1 - 3 } YES & 84 & 8 & $\mathrm{p}^{\prime}=0.1404 * *$ \\
\cline { 1 - 3 } NO & 6 & 2 & \\
\hline
\end{tabular}

Source: Primary Data, ${ }^{* *}$ shows significance at 5\%

\section{Interpretation}

The Table No. 3.2.4 shows that $84 \%$ of the married respondents have agreed that they invest in gold. Only $8 \%$ of the respondent unmarried invests in gold. The chi-square test was applied to find the association between marriage and investment in gold. In Kerala gold investment is done mostly during the marriage and after marriage. The results show that the variables are having a significant association between them as the ' $p$ ' value is 0.1404 , which is less that $0.5 \%$ level of 
significance.( $\mathrm{p}$ value is the probability that a chi-square value is more extreme than 19.58 i.e., $(\mathrm{p}>19.58)$

\subsubsection{Employment}

Investment needs money and without employment people cannot have much savings for investing. The total respondents are classified as employed in Govt. Service, Private Service.

Table 5: Employment and Investment

\begin{tabular}{|l|l|l|l|}
\hline INVEST & GOVT & PVT & \multirow{2}{*}{} \\
\cline { 1 - 2 } Yes & 58 & 36 & $\chi 2.89$ \\
\cline { 1 - 2 } No & 2 & 4 & $\mathrm{P}=0.1691 * *$ \\
\hline
\end{tabular}

Source: Primary Data, ** Shows Significance At 5\%

\section{Interpretation}

The Table No. 3.2.5 shows that $58 \%$ of the respondents employed in Govt. Service invest in gold and about $36 \%$ of respondents employed privately invest in gold. A chi-square test was done, and the results gave a value of 1.89 with 1 degree of freedom, and the ' $p$ ' value obtained is 0.1691. As the ' $p$ ' value is significant; i.e., it is more than 0.5 level of significance. $p$ value is the probability that a chi-square value is more extreme than 19.58 i.e., ( $>$ > 19.58) This shows that those who are employed in Govt. Service are more regular income people and really afford to buy gold which is a luxury item.

\subsubsection{Income Level}

The income available for necessities such as food, cloth, transportation, shelter, and utilities, has greater influence in taking investment decision. Also, complex adjustments are necessary for household size, area of residence, and other demographic characteristics. The family income must be high enough to satisfy nearly all our important desires. One of the most significant developments of this decade and beyond is the changing nature of income levels. The following table presents the classification of the respondents according to their income

Table 6: Income and Investment in Gold

\begin{tabular}{|c|c|c|c|c|c|}
\hline INVEST & < 2 LAC & 2 LAC - 4 LAC & 4LAC - 6LAC & >6LAC & \multirow{2}{*}{} \\
\cline { 1 - 5 } YES & 22 & 26 & 28 & 16 & $\chi^{2}=4.50$ \\
\cline { 1 - 5 } NO & 4 & 0 & 2 & 2 & $\mathrm{P}=0.2126^{* *}$ \\
\hline
\end{tabular}

\section{Interpretation}

The variable income level is classified between the ranges less than 2 lakh, 2- 4 lakhs 4-6 lakh, more than 6 lakhs. The table shows that at least 22 samples earning less than 2 lakh invest in gold, Respondents earning between 2-4 lakh who invest in gold is around 26. Respondents earning 4-6 lakh who invest in gold is 28 and about 6 respondents having an income above 6 lakh have said that they invest in gold. A chi-square test was applied and ' $p$ ' value obtained is .2126 , which indicate that it is significant than the $.5 \%$ level of significance. 


\subsection{Factors Influencing Investment Decision on the Kind of Gold}

\subsubsection{Alternative-An Analysis}

People invest their savings to get a profitable return. Demographical factors have shown differences in selecting various investment alternatives among investors. This section deals with the analysis of demographical differences with variables like education, marital status, occupation and income level while investing in various gold alternatives. These four variables have a greater influence in deciding the kind of gold investment an investor should make.

\subsubsection{Education}

Investors are basically of two categories, one risk averse and other risk taking. Education has an important role in making decision regarding investment. Awareness about various investment avenues, their risk, market price, market return, etc., will really help an investor in a profitable investment. Here we took 100 samples to analyse whether education qualification is independent on the decision in alternative gold investment.

Table 7: Education and Kind of Gold Investment

\begin{tabular}{|c|c|c|c|c|}
\hline INVEST & PG & GRADUATE & $\mathrm{SSLC} /+2$ & \multirow{9}{*}{$\begin{array}{c}\chi^{2}=30.64 \\
\mathrm{P}=0.0149 * *\end{array}$} \\
\hline JWELLERY & 24 & 14 & 2 & \\
\hline GOLD ETF & 12 & 22 & 0 & \\
\hline GOLD BULLION & 2 & 2 & 2 & \\
\hline GOLD BOND & 0 & 2 & 0 & \\
\hline GOLD COIN & 4 & 6 & 0 & \\
\hline GOLD MF & 2 & 2 & 0 & \\
\hline E-GOLD & 0 & 2 & 0 & \\
\hline GOLD FUTURES & 0 & 2 & 0 & \\
\hline
\end{tabular}

Source: Primary Data, $* *$ indicate significance at $5 \%$

\section{Interpretation}

The table above shows that investors irrespective of their qualification prefer jewellery and Gold ETF when compared to other forms of gold investment. A chi-square test was applied and results show a value of 30.64, with degree of freedom, 16. The ' $p$ ' value obtained is .0149 which is significant at $5 \%$ level of significance. This means that educational qualification influence different forms of gold investment like gold ETF

\subsubsection{Marital Status}

Married men and women have their family responsibilities and they are more worried about their future than the unmarried people. Therefore the perception about the kind of investment also varies. The following analysis is done by categorizing different forms of investments preferred by married and unmarried respondents. 
Table 8: Marital Status and Kind Os Investments

\begin{tabular}{|c|c|c|c|}
\hline INVEST & MARRIED & SINGLE & \multirow{9}{*}{$\begin{array}{c}\chi^{2}=23.03 \\
\mathrm{P}=0.0033^{*} *\end{array}$} \\
\hline JWELLERY & 32 & 6 & \\
\hline GOLD ETF & 34 & 2 & \\
\hline GOLD BULLION & 6 & 0 & \\
\hline GOLD BOND & 2 & 0 & \\
\hline GOLD COIN & 10 & 0 & \\
\hline GOLD MF & 4 & 0 & \\
\hline E-GOLD & 2 & 0 & \\
\hline GOLD FUTURES & 0 & 2 & \\
\hline
\end{tabular}

Source: Primary Data, ** indicate significance at 5\%

\section{Interpretation}

Marital status is an important variable while studying the factors that influence investors in selecting the kind of investment. After marriage the sense of responsibility increases towards the family and investors will decide their investment according to the need of the family. Here, we can see that married investor prefers Jewellery and gold ETF when compared to other forms of gold investment. In India among the various kinds of gold investment Jewellery is the post popular.

\subsubsection{Employment}

Occupation is another important variable when alternative gold investments are concerned. For this analysis the occupation level is categorised as Government employees, Private employees, and self-employed.

Table 9: Employment and Kind of Investment

\begin{tabular}{|c|c|c|c|c|}
\hline INVEST & GOVT & PVT & SELF & \multirow{9}{*}{$\begin{array}{l}\chi^{2}=23.03 \\
\mathrm{P}=0.0033 * *\end{array}$} \\
\hline JWELLERY & 18 & 12 & 8 & \\
\hline GOLD ETF & 10 & 22 & 4 & \\
\hline GOLD BULLION & 2 & 2 & 2 & \\
\hline GOLD BOND & 0 & 2 & 0 & \\
\hline GOLD COIN & 4 & 0 & 6 & \\
\hline GOLD MF & 2 & 0 & 2 & \\
\hline E-GOLD & 0 & 2 & 0 & \\
\hline GOLD FUTURES & 0 & 0 & 2 & \\
\hline
\end{tabular}

(Source: Primary Data), ** indicate significance at 5\%

\section{Interpretation}

A chi-square test was applied and the results shows that the hypothesis that marital status has an influence in the kind of gold investment respondents selects is accepted as ' $p$ ' value is significant with a .0035 at $5 \%$ level of significance. Therefore we can say that occupational category is not independent with the decision of selecting the various forms of gold investments alternative. 


\section{Income}

The family income is a high influential variable while making investments especially in luxury investments like gold. To analyse this variable the total respondents were classified into four categories according to their annual income

Table 10: Income and Kind of Gold Investment

\begin{tabular}{|c|c|c|c|c|c|}
\hline $\begin{array}{l}\text { KIND OF GOLD } \\
\text { INVESTMENT }\end{array}$ & $<2$ LAC & $2 \mathrm{LAC}-4 \mathrm{LAC}$ & 4LAC - 6LAC & $>6 \mathrm{LAC}$ & \multirow{9}{*}{$\begin{array}{l}\chi^{2}=62.76 \\
P=2.57 E-05 \\
(0.000)\end{array}$} \\
\hline JWELLERY & 10 & 4 & 8 & 16 & \\
\hline GOLD ETF & 12 & 12 & 12 & 0 & \\
\hline GOLD BULLION & 2 & 2 & 2 & 0 & \\
\hline GOLD BOND & 0 & 2 & 0 & 0 & \\
\hline GOLD COIN & 0 & 2 & 6 & 2 & \\
\hline GOLD MF & 2 & 0 & 2 & 0 & \\
\hline E-GOLD & 0 & 2 & 0 & 0 & \\
\hline GOLD FUTURES & 0 & 2 & 0 & 0 & \\
\hline
\end{tabular}

Source: Primary Data, $* *$ indicate significance at 5\%

\section{Interpretation}

A chi-square test was applied to analyse how differences in income level will influence investors in the selection of gold investment alternatives. The test gave a value of 62.76 with a degree of freedom 24. The ' $p$ ' value $2.57 \mathrm{E}(0.000)$ which means this variable has an impact while making investment in gold. As 44 among the respondents are female, there selection of form of gold investment will be different from male. Moreover, higher qualified investors will look for investments which minimizes their risk and bring appreciation in their wealth.

\section{Findings and Conclusions}

\subsection{Findings}

This study is based on both the primary data and secondary data. The Primary data was analysed by sung Chi-square test and the secondary data was analysed by using an econometric model GARCH $(1,1)$. The important findings of the study are the following:-

1) The first objective " Gold is a safer investment when compared to other alternative investments ' is analyzed by a risk and return analysis of Gold daily prices, daily stock index(Nifty50) and daily bond (India Govt.) yield for a period 2012-2017 by estimating GARCH(1,1) model using E-views software. GARCH $(1,1)$ model is a econometric model used to estimate the daily volatility between gold prices, daily stock index, and daily bond yield. The findings shows that risk in terms of volatility of gold prices is $0.970124(<1)$ when compared to daily volatility of stock index which is $0.956541(<1)$ and that of daily bond yield is $1.003183(>1)$. This means that risk is less in the case of gold investment when compared to stock and bond as daily volatility is less in gold prices than the daily volatility of stock and bond. The results also shows that the risk 
of bond yield (the risk free investment) is 1.003183 which means there is an increase volatility in the daily bond yield when compared to daily gold prices and daily stock index. Thus the hypothesis that gold is a safer investment among other alternative (stock index, bond yield) is accepted.

2) The second objective 'factor influencing investors decision to invest in gold or not is analyzed using a Chi-Square test. The results shows that all the variable under study( Age, Gender , Employment, Income level, Marital status) dictated the investors in the decision to invest in gold or not except educational qualification. The chi-square value on the analysis of educational qualification and investment showed a ' $p$ ' value of 0.8308 , greater than the $0.5 \%$ significance level, which means educational qualification as a variable is not significant to investors while taking decisions to invest in gold or not.

3) The third objective 'Factors influencing the investor's decision on the kind of gold investment was also analysed using a Chi-Square test. All the variables under study such as Educational level, Employment, Marital status, Income level showed a 'p' value less than $0.5 \%$ level of significance which says that all the four variables influences the decision of the investors while selecting different forms of gold investment alternative.

\subsection{Conclusion}

This project investigates 'gold as a safer investment alternative among other investment' by conducting a risk and return analysis of gold prices, stock index and bond yield for a period $1^{\text {st }}$ quarter of 2012- $1^{\text {st }}$ quarter of 2017. A GARCH $(1,1)$ model was estimated to understand the daily volatility between the daily gold prices, daily stock index, and bond yield. The results show that the daily volatility of gold prices is less when compared to stock index and bond yield. The daily volatility of bond yield is high inspite of its being considered as the risk free The study also found that when various factors (age, gender, educational level, marital status, income level) that influence investors to make investment in gold was analysed educational qualification as a variable was not found significant ('p'=0.8308) at 5\% level of significance.

\section{References}

[1] Dirk G. Baur, Thomas K. McDermott, Is gold a safe haven? International evidence,In Journal of Banking \& Finance, Volume 34, Issue 8, 2010, Page 1886-1898

[2] Rangan Gupta, Anandamayee Majumdar, Christian Pierdzioch, Mark E. Wohar, Do terror attacks predict gold returns? Evidence from a quantile-predictive-regression approach, In The Quarterly Review of Economics and Finance, Volume 65, 2017, Pages 276-284, ISSN 1062-9769,

[3] Christian Pierdzioch, Jan-Christoph Rülke, Georg Stadtmann, A note on forecasting the prices of gold and silver: Asymmetric loss and forecast rationality, In The Quarterly Review of Economics and Finance, Volume 53, Issue 3, 2013, Pages 294-301, ISSN 1062-9769.

[4] Gupta, Rangan, et al. "Do terror attacks predict gold returns? Evidence from a quantilepredictive-regression approach." The Quarterly Review of Economics and Finance (2017).

[5] Mishra, Shekhar, and Sathya Swaroop Debasish. "An Econometric Study of Trading Behaviour of Institutional Investors in Indian Stock Market: The Vector Auto Regression Approach." IIMS Journal of Management Science 8.2 (2017): 155-172.

[6] Cuong Nguyen, M. Ishag Bhatti, Magde Komornikova, Jozef Komornikova; Economic Modelling vol. 58, Nov. 2016.

[7] Pullen, Tim, Karen Benson, and Robert Faff. "A comparative analysis of the investment characteristics of alternative gold assets." Abacus 50.1 (2014): 76-92. 
[8] Hood, Matthew, and Farooq Malik. "Is gold the best hedge and a safe haven under changing stock market volatility?." Review of Financial Economics 22.2 (2013): 47-52.

[9] Ghazali, Mohd Fahmi, Hooi Hooi Lean, and Zakaria Bahari. "Sharia compliant gold investment in Malaysia: Hedge or safe haven?." Pacific-Basin Finance Journal 34 (2015): 192-204.

[10] Sindhu, Dr. "A study on impact of select factors on the price of Gold." India: School of Management Studies, Jawaharlal Nehru Technological University Hyderabad (2013).

[11] Jain, Anshul, and P. C. Biswal. "Dynamic linkages among oil price, gold price, exchange rate, and stock market in India." Resources Policy 49 (2016): 179-185.

[12] Mishra, P. K., J. R. Das, and S. K. Mishra. "Gold price volatility and stock market returns in India." American Journal of Scientific Research 9 (2010): 47-55.

[13] Mishra, Shekhar, and Sathya Swaroop Debasish. "An Econometric Study of Trading Behaviour of Institutional Investors in Indian Stock Market: The Vector Auto Regression Approach." IIMS Journal of Management Science 8.2 (2017): 155-172.

[14] Sardar, Ramesh J., and AARTI KANTILAL JAIN. "Marketing strategies of Gold Merchant's in Fluctuating Gold Prices at Manmad City." International Research Journal of Multidisciplinary Studies 2.4 (2016).

[15] Gangopadhyay, Kausik, Abhishek Jangir, and Rudra Sensarma. "Forecasting the price of gold: An error correction approach." IIMB Management Review28.1 (2016): 6-12.

\footnotetext{
*Corresponding author.

E-mail address: shobhagopinathnair@ gmail.com
} 